\title{
The Application of Non-chloride Based Disinfectants in Inactivation of SARS-CoV-2 in Personal Protective Equipment, Air and Surfaces of Hospitals
}

\author{
Hastanelerdeki Kişisel Koruyucu Donanımlarda, Havada ve Yüzeylerde SARS-CoV-2'nin \\ Inaktivasyonunda Klorür Esaslı OImayan Dezenfektanların Uygulanması
}

\author{
(D) Amirabbas NIKMARAM \\ Cyprus International University Faculty of Pharmacy, Nicosia, TRNC
}

\section{Abstract}

As Severe acute respiratory syndrome-Coronavirus-2 (SARS-CoV-2) emerged in 2019, scientists sought to find a way of inactivating this new virus to effectively disinfect surfaces, air, hands, etc. The first proposed manners were on the basis of chemical disinfectants such as chlorine and bleach, however, application of these methods can result in some hazards for human beings and the environment. Therefore, new methods such as ultraviolet (UV) radiation were recommended. Not only these new methods can accelerate the inactivation of SARS-CoV-2 in a more efficient way, their hazards and side effects are also less when compared to chlorine-based disinfectants. In this review, we discussed the utilization of UV-C, hydrogen peroxide, ozone, and cold plasma as new, nonthermal methods to disinfect personal protective equipment, air, and surfaces in hospitals, since hospitals were one of the major sources of Coronavirus disease-2019 infection and members of health care team were highly prone to being infected.

Keywords: COVID-19, disinfectants, hospital infections, pandemic, SARS-CoV-2 inactivation

Öz

2019'da Şiddetli akut solunum sendromu-Koronavirüs-2'nin (CoV-2) ortaya çıkması ile bilim adamları yüzeyleri, havayı, elleri vb. etkili bir şekilde dezenfekte etmek için bu yeni virüsü etkisiz hale getirmenin bir yolunu bulmaya çalıştılar. Önerilen ilk yöntemler, klor ve ağartıcı gibi kimyasal dezenfektanlara dayanıyordu, ancak bu yöntemlerin uygulanması insan ve çevre için bazı riskler taşıyordu. Bu nedenle ultraviyole (UV) radyasyon gibi yeni yöntemler önerildi. Şiddetli akut solunum sendromu-CoV-2'nin etkisiz hale getirilmesini daha verimli bir şekilde hızlandıran bu yeni yöntemler, klor bazlı dezenfektanlara kıyasla daha az risk taşımaktadır ve daha az yan etkiye sahiptir. Bu derlemede, hastaneler Koronavirüs hastalığı-2019 enfeksiyonunun ana kaynaklarından biri olduğundan ve sağlık ekibinin üyeleri enfekte olmaya oldukça yatkın oldukları için hastanelerde kişisel koruyucu donanımları, havayı ve yüzeyleri dezenfekte etmek için yeni, termal olmayan yöntemler olarak UV-C, hidrojen peroksit, ozon ve soğuk plazmanın kullanımını tartıştık.

Anahtar Kelimeler: COVID-19, dezenfektanlar, hastane enfeksiyonları, pandemi, SARS-CoV-2 inaktivasyonu

\section{Introduction}

In December 2019, a group of people started to arrive at Wuhan's hospitals with severe pneumonia of unknown etiology.
This was reported to the World Health Organization (WHO), and on January 7, 2020, a new coronavirus was found among these patients, which was officially called Severe acute respiratory syndrome-Coronavirus-2 (SARS-CoV-2) ${ }^{[1]}$. This new virus causes

Cite this article as: Nikmaram A. The Application of Non-chloride Based Disinfectants in Inactivation of SARS-CoV-2 in Personal Protective Equipment, Air and Surfaces of Hospitals. Mediterr J Infect Microb Antimicrob. 2022;11:12. 
a disease called Coronavirus disease-2019 (COVID-19), which has nosocomial transmission capacity ${ }^{[2,3]}$.

Till now, a definitive cure for COVID-19 is not been achieved, thus people try to apply preventive strategies, such as isolating infected people, obeying the social distancing rules, using personal protective equipment (PPE), and applying effective disinfection methods ${ }^{[4-7]}$.

However, the application of these methods faces difficulties. During the current pandemic, a global shortage of PPE has been experienced, and the WHO recognizes that the current global stockpile has been inadequate, especially for surgical masks and filtering facepiece respirators (FFRs) ${ }^{[8]}$. Disinfecting and reusing PPE (particularly FFRs) can be an effective way to deal with the unprecedented PPE shortage ${ }^{[9,10]}$.

In addition to the use of PPE, disinfection of surfaces is very necessary to prevent SARS-CoV-2 transmission ${ }^{[11]}$. Therefore, chloride-based disinfectants are commonly used in hospitals to disinfect surfaces. However, thorough manual surface cleaning may be insufficient to completely diminish pathogens or viral transmission ${ }^{[12]}$. Moreover, chlorine-based disinfectants can have harmful effects on the human respiratory system ${ }^{[13]}$ and may damage the ecology and environment ${ }^{[14]}$. Therefore, new alternative methods with higher efficacy should be applied ${ }^{[12]}$.

This study aimed to investigate the efficiency of new approaches against SARS-CoV-2. These alternative methods are usually more efficient (in disinfecting this virus) than the common methods and do not possess the risks and side effects of chloride-based disinfectants ${ }^{[12,15]}$

\section{SARS-CoV-2 Stability on Different Surfaces and} Its Surrogates

Recent studies showed that SARS-CoV-2 has different stabilities on different surfaces (Table 1). The SARS coronavirus maintains its stability and viability on smooth surfaces in normal air conditions (temperature of $22-25{ }^{\circ} \mathrm{C}$ and relative humidity of 40-50\%) for over 5 days. However, viral stability remarkably diminishes ( $>3 \log$ reduction) at higher relative humidity and temperature (e.g., $8{ }^{\circ} \mathrm{C}$ and $95 \%$, respectively) ${ }^{[16]}$. It clarifies why some tropical Asian countries (Malaysia, Thailand, and Indonesia) with elevated temperatures and high humidity have not experienced severe SARS outbreaks in their populations ${ }^{[16]}$.

Researching SARS-CoV-2 may be highly dangerous since scientists are at risk of infection and the use of surrogate coronaviruses can cross these hurdles ${ }^{[17]}$. Bacteriophages represent strong surrogates for airborne virus research, and specific precautions for biocontainment are not required, as they are riskless for humankind ${ }^{[18,19]}$.
Bacteriophage's diversities are high on both genetic and morphological levels, which provide a large pool of pathogens, wherein some phages share structural similarities with eukaryotic viruses ${ }^{[20]}$. Furthermore, double-stranded DNA genome-tailed phages (Caudovirales) seem to be the most studied of all bacterial viruses and can be used in a wide range of applications that involve aerosol investigations (Figure 1) ) $^{[21]}$. The following surrogates were used (for literature studies) to evaluate the effectiveness of disinfectants against coronaviruses based on biophysical properties and genomic structures: Human coronavirus $229 \mathrm{E}$, murine hepatitis virus, transmissible gastroenteritis virus, and feline infectious peritonitis virus ${ }^{[22]}$.

\section{Ultraviolet}

Based on the purpose of this study, ultraviolet (UV) light is classified into three different groups of wavelength as follows: UVA (320-400 nm), UVB (280-320 nm), and UVC (200-280 $\mathrm{nm})^{[23]}$. UVC light has much greater germicidal characteristics than both UVA and UVB since UVC photons can be sensitively absorbed by the intercellular constituent of pathogens (like
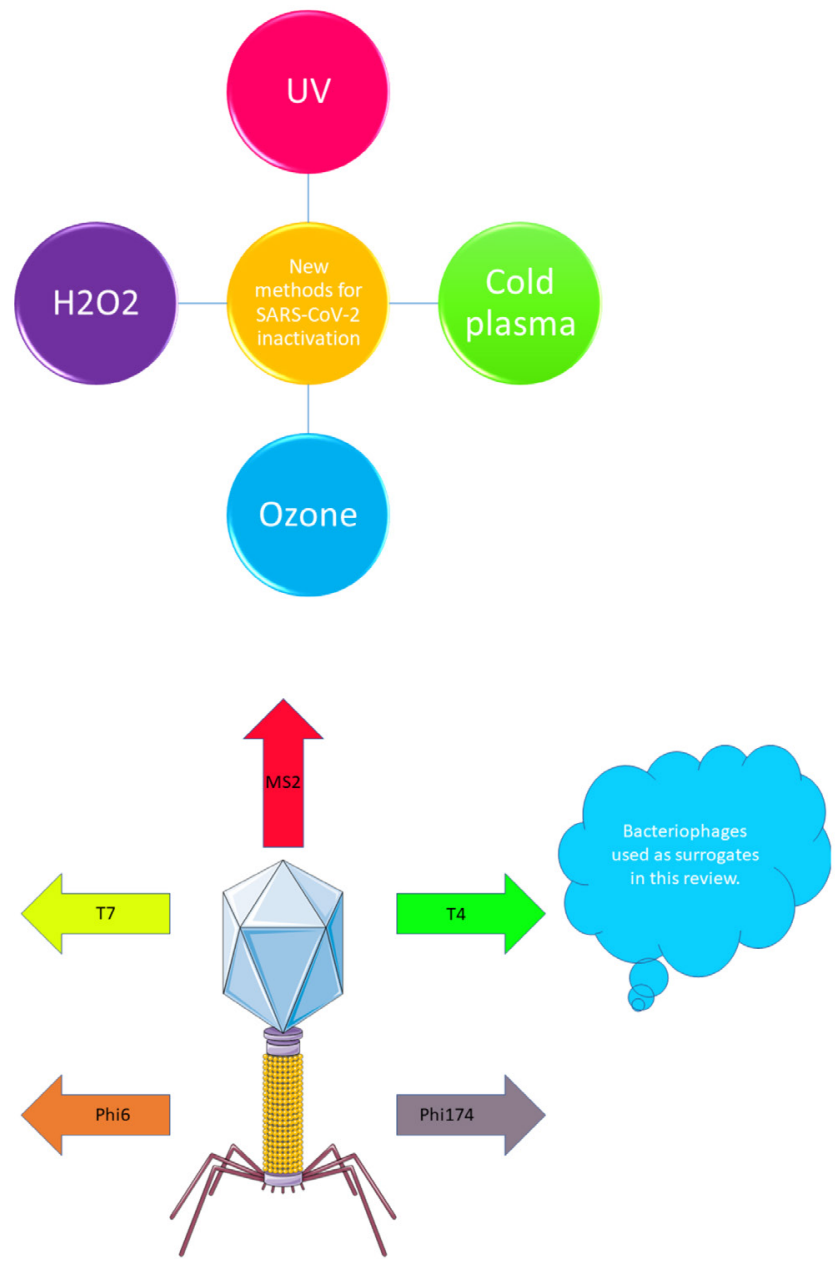

Figure 1. The bacteriophages which can be surrogates of Severe acute respiratory syndrome-Coronavirus-2 
RNA, DNA, and proteins) and it disables viruses to replicate (Table 2) ${ }^{[10,24]}$.

Moreover, research findings prove that UV is a reliable virucidal technique. Tseng and $\mathrm{Li}^{[25]}$ tested the effectiveness of UV against viruses, which were on the surface of gelatin made medium (Table 3), and evaluated the susceptibility of four different viruses according to their genome. They revealed that UV is a reliable and effective method to disinfect surfaces.

Several studies have examined the effectiveness of UV in microorganism inactivation on the PPE. A study evaluated the influence of pulsed xenon ultraviolet (PX-UV) cleaning on an Ebola-surrogate virus on crystal containers and PPE content to explore its possible benefits in PPE decontamination ${ }^{[26]}$. This study aimed to decrease the pathogen loading before doffing. They discovered that PX-UV exposure significantly reduced the viral load of glass containers and PPE.

However, the efficacy of UV radiation is dependent on the dose or fluence and shadowing, as it solely inactivates by the irradiation of media ${ }^{[27]}$, and high doses of UV can cause changes in the penetration and resistance of PPE ${ }^{[28]}$.

\section{Ozone}

Ozone is a potent oxidizing agent that is widely used in the pharmaceutical and food industries, as well as in the environmental regulation of pathogenic microorganisms (Table 4) ${ }^{[29-31]}$. Compared with the chlorine-based disinfectants, ozone is 25 times more powerful than Hypo chloric acid and 2,500-3,000 times more effective than hypochlorite $\left(\mathrm{OCl}^{-}\right)^{[32]}$. Furthermore, ozone gas production is easier, more economical, and safer to handle and apply ${ }^{[33]}$. Additionally, ozone molecules can easily decompose back to oxygen, thus the environmental hazards may be decreased ${ }^{[34]}$.

There are currently no investigations that explicitly evaluate ozone's disinfection method against SARS-CoV-2. However, Tizaoui ${ }^{[35]}$ believe that ozone would attack the spike proteins and lipid envelope of SARS-CoV-2, which would therefore inhibit its capability to bind to cell receptors and replicate in cells.

Additionally, the use of pseudoviruses (as a model for testing coronavirus) at different ozone concentrations has been studied. Exposure of these viruses to ozone for $20 \mathrm{~min}$ at $1000 \mathrm{ppm}, 30$ min at 100 ppm, and approximately $40 \mathrm{~min}$ at $30 \mathrm{ppm}$ decreased the viral infection by $95 \%$. These results suggest that even at

Table 1 . The stability of SARS virus on different surfaces ${ }^{[61]}$

\begin{tabular}{llll}
\hline Type of surface & Type of SARS corona virus & Temperature & Persistence \\
\hline Metal & Genetic variant P9 & Room temperature & 5 days \\
\hline Wood & Genetic variant P9 & Room temperature & 4 days \\
\hline Paper & Genetic variant P9 & Room temperature & $4-5$ days \\
\hline Paper & Genetic variant GVU6109 & Room temperature & 24 hours to <5 min \\
\hline Glass & Genetic variant P9 & Room temperature & 4 days \\
\hline Plastic & Genetic variant HKU39849 & $22-25{ }^{\circ} \mathrm{C}$ & $\leq 5$ days \\
\hline Plastic & Genetic variant P9 & Room temperature & 4 days \\
\hline Plastic & Genetic variant FFM1 & Room temperature & $6-9$ days \\
\hline Disposable gown & Genetic variant GVU6109 & Room temperature & 2 days to 1 hour
\end{tabular}

SARS: Severe acute respiratory syndrome

Table 2. The sensitivity of different coronaviruses to UVC ${ }^{[62]}$

\begin{tabular}{llll}
\hline Virus & Irradiation wavelength $(\mathbf{n m})$ & Log reduction dose $\left(\mathbf{m} \mathbf{J} / \mathbf{c m}^{2}\right)$ & Sample condition \\
\hline HCoV-229E & 222 & 0.56 & Aerosol \\
\hline MHV & 254 & 0.66 & Aerosol \\
\hline MERS COV & 254 & Successful inactivation & Droplets \\
\hline TGEV & 254 & 3.68 & Liquid (with 10\% blood platelet concentrate) \\
\hline SARS-CoV-1 & 254 & 4.6 & Aliquots of virus \\
\hline SARS-CoV-2 & $260-285$ & $\geq 4$ & Stainless steel \\
\hline CCoV L-71 & 254 & 10.55 & Liquid (thin layer of cell culture with fetal bovine \\
& & & serum)
\end{tabular}

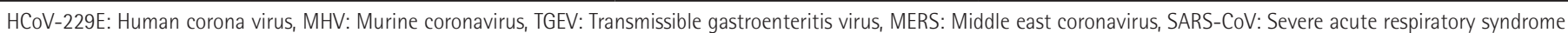
coronavirus, CCoV: Canine coronavirus 
low ozone exposure, ozone is an effective disinfectant for the enveloped pseudoviruses ${ }^{[36]}$.

Ozone can be utilized as a sanitizer/disinfectant in both aqueous and gaseous forms in several industrial and home settings. Ozone is more reactive in its gaseous form; however, aqueous ozone disinfection is advantageous. Thus, controlling the oxidant concentration of ozone in liquid form is easier ${ }^{[29,37]}$. Additionally, despite the complications associated with breathing ozone in a gaseous state, aqueous ozone does not affect human skin cells since its cell destruction effect is specific to microbial cells ${ }^{[38]}$. Finally, ozonated water shows limited cytotoxicity to human keratinocytes as experimentally compared with different hand disinfectants ${ }^{[39]}$.

Moreover, ozone can be used to inactivate microorganisms on the surfaces of PPE and enable its reuse (Figure 2) ${ }^{[40]}$. Furthermore, exposure to the suggested dose of ozone does not change the efficiency of $\mathrm{N} 95$ filtering materials ${ }^{[40]}$. Subsequent tests showed no loss of filtration efficiency or mechanical properties for either substance when exposed to 20 ppm ozone for up to $36 \mathrm{~h}$, thus corresponding to 7230 minutes disinfection cycles at 20 ppm $^{[41]}$.

\section{Cold Plasma}

The fourth state of matter is plasma. It is a partially or completely ionized gas where the outer-shell electrons are stripped of the atoms and/or molecules ${ }^{[42]}$. Among the plasma's various constituents, UV radiation and reactive oxygen and/or nitrogen molecules have the most essential antimicrobial capabilities ${ }^{[43]}$. Production of ROS and RNS leads to the breakage of $\mathrm{C}-\mathrm{C}, \mathrm{C}-\mathrm{O}$, and $\mathrm{C}-\mathrm{N}$ bonds of microorganisms ${ }^{[44]}$. The level of these reactive species can be modified by plasma source design, operating conditions, feeding gas types, and the microorganism itself ${ }^{[45]}$. Plasma can be roughly classified into thermal (or equilibrium plasma) and nonthermal [nonequilibrium or cold plasma (CP)]. The CP method can be used at room temperature and thus is ideal for the different biological materials, including solids, aerosols, and liquids ${ }^{[46]}$.

In replacing traditional disinfectant methods for the inactivation of viruses, $\mathrm{CP}$ has shown great promise ${ }^{[47]}$. Wu et al. ${ }^{[48]}$ evaluated the efficacy of atmospheric pressure CP (APCP) against the MS2 virus and revealed that the MS2 virus survival levels (for the airborne states) were significantly reduced by APCP exposure. Additionally, >95\% (1.3 log reduction) of the viruses, which were in the air, were inactivated by the APCP

Table 3. The inactivation of different viruses by UV irradiation ${ }^{[63]}$

\begin{tabular}{lll}
\hline Virus genome type & Amount of inactivation & \multicolumn{1}{c}{ The required dose of UV $\left.\mathbf{( m J}^{\mathbf{c}} \mathbf{c m}^{\mathbf{2}}\right)$} \\
\hline \multirow{2}{*}{ ssRNA } & $90 \%$ & $1.32-3.20$ \\
\cline { 2 - 3 } & $99 \%$ & $2.51-6.5$ \\
\hline \multirow{2}{*}{ sSDNA } & $90 \%$ & $2.5-4.47$ \\
\cline { 2 - 3 } & $99 \%$ & $5.04-8.34$ \\
\hline dsRNA & $90 \%$ & $3.80-5.36$ \\
\cline { 2 - 3 } & $99 \%$ & $7.75-10.57$ \\
\hline dsDNA & $90 \%$ & $7.70-8.13$ \\
\cline { 2 - 3 } & $99 \%$ & $15.54-16.20$ \\
\hline
\end{tabular}

ssRNA: Single-stranded RNA, dsRNA: Double-strand RNA, ssDNA: Single-stranded DNA, dsDNA: Double-stranded DNA, the RH (relative humidity) is 55\%, UV: Ultraviolet

Table 4. The effectiveness of ozone molecule in inactivation of some aerosol viruses ${ }^{[64]}$

\begin{tabular}{|c|c|c|c|c|c|c|}
\hline Name of virus & Genome & Size $(n m)$ & Envelop & $\mathrm{RH}$ value & Inactivation & Ozone concentration (ppm) \\
\hline \multirow[t]{2}{*}{ MS2 } & ssRNA & 25 & NO & $55 \%$ & $90 \%$ & 3.43 \\
\hline & & & & & $99 \%$ & 6.63 \\
\hline \multirow[t]{2}{*}{ Phi X174 } & ssDNA & $25-27$ & NO & $55 \%$ & $90 \%$ & 1.87 \\
\hline & & & & & $99 \%$ & 3.84 \\
\hline \multirow[t]{2}{*}{ Phi 6} & dsDNA & $75-86$ & YES & $55 \%$ & $90 \%$ & 1.16 \\
\hline & & & & & $99 \%$ & 2.5 \\
\hline \multirow[t]{2}{*}{ T7 } & dsDNA & 45 & NO & $55 \%$ & $90 \%$ & 5.20 \\
\hline & & & & & $99 \%$ & 10.33 \\
\hline
\end{tabular}

The contact time in this experiment was 13.8 seconds. 


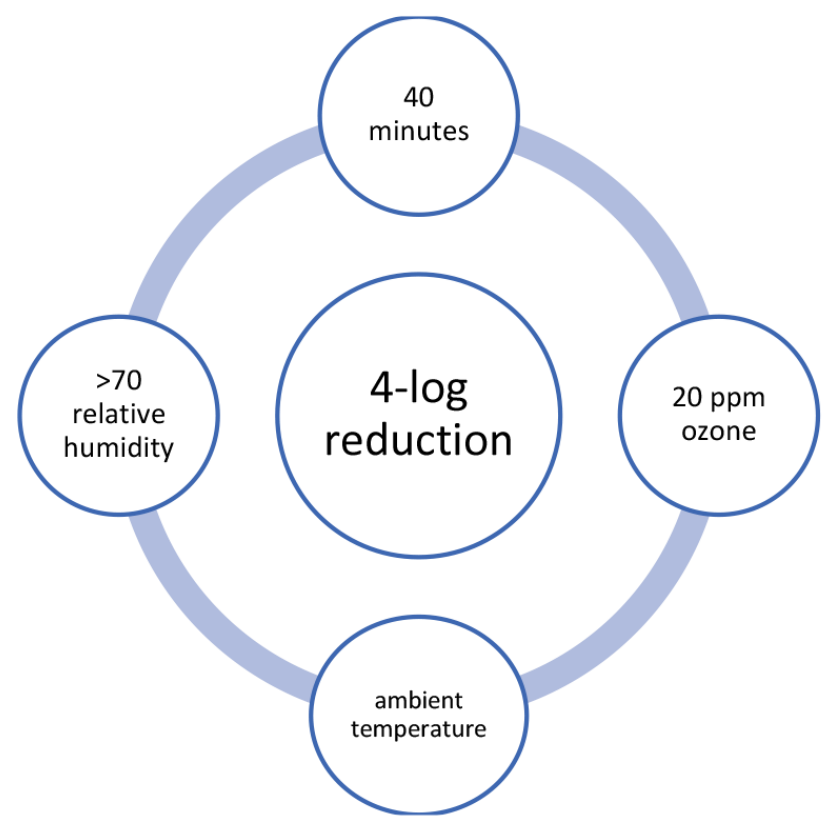

Figure 2. Condition needed to inactivate Severe acute respiratory syndrome-Coronavirus-2 on personal protective equipments and surfaces using ozone

application (utilization of ambient air as the gas transporter) at 28 Watts for approximately 0.12 seconds. Furthermore, influenza $A$ and $B$ viruses and respiratory syncytial virus (RSV) have been treated with the pulsed high-voltage CP source ${ }^{[49,50]}$ and revealed that $\mathrm{CP}$ treatment can completely inactivate the RSV on the surface of the glass after 5 min of exposure $^{[49]}$. Lastly, treatment with Ar-fed cold atmospheric plasma (CAP) has been proven to rapidly and effectively disable SARS-CoV-2 on a wide variety of surfaces (including plastic, metal, and cardboard) that people regularly touch ${ }^{[11]}$. Therefore, CAP can be a confident and efficient way to avoid viral transmission and infection.

\section{Hydrogen Peroxide $\left(\mathrm{H}_{2} \mathrm{O}_{2}\right)$}

$\mathrm{H}_{2} \mathrm{O}_{2}$ is a powerful and potent oxidant, which works against different microorganisms (such as viruses and bacteria) by the formation of HO (Figure 3) ${ }^{[52,53]}$. It is used for preserving, disinfecting, and sterilizing applications in both liquid and gas types. The $\mathrm{H}_{2} \mathrm{O}_{2}$ gas method has become a common alternative to the other physical and chemical-based antimicrobial techniques because of its low temperature, rapid efficacy, limited toxicity concerns, and compatibility with surface materials ${ }^{[54]}$.

Two different commercial vaporized $\mathrm{H}_{2} \mathrm{O}_{2}$ generation systems are offered to decontaminate microbiological laboratories. The first one is $\mathrm{H}_{2} \mathrm{O}_{2}$ vapor (HPV) and the second one is vapor $\mathrm{H}_{2} \mathrm{O}_{2}$ (VHP). The HPV approach infuses HPV at a low level into the enclosures, thus small condensation occurs on the inside surface. VHP, on the other hand, works as a dry device, lowering the humidity levels inside the enclosures and preventing condensation on surfaces $^{[55]}$. The Environmental Protection Agency registers both condensing and non-condensing systems and both are effective against bacterial spores and other microorganisms ${ }^{[56-58]}$.

Saini et al. ${ }^{[59]}$ studied the efficacy of $\mathrm{H}_{2} \mathrm{O}_{2}$ in decontamination of different PPE, including face shields, coveralls, and N95 masks. Three biological markers, namely Mycobacterium smegmatis, Escherichia coli, and Bacillus stearothermophilus spores, are regarded as the gold standard for inactivation processes,

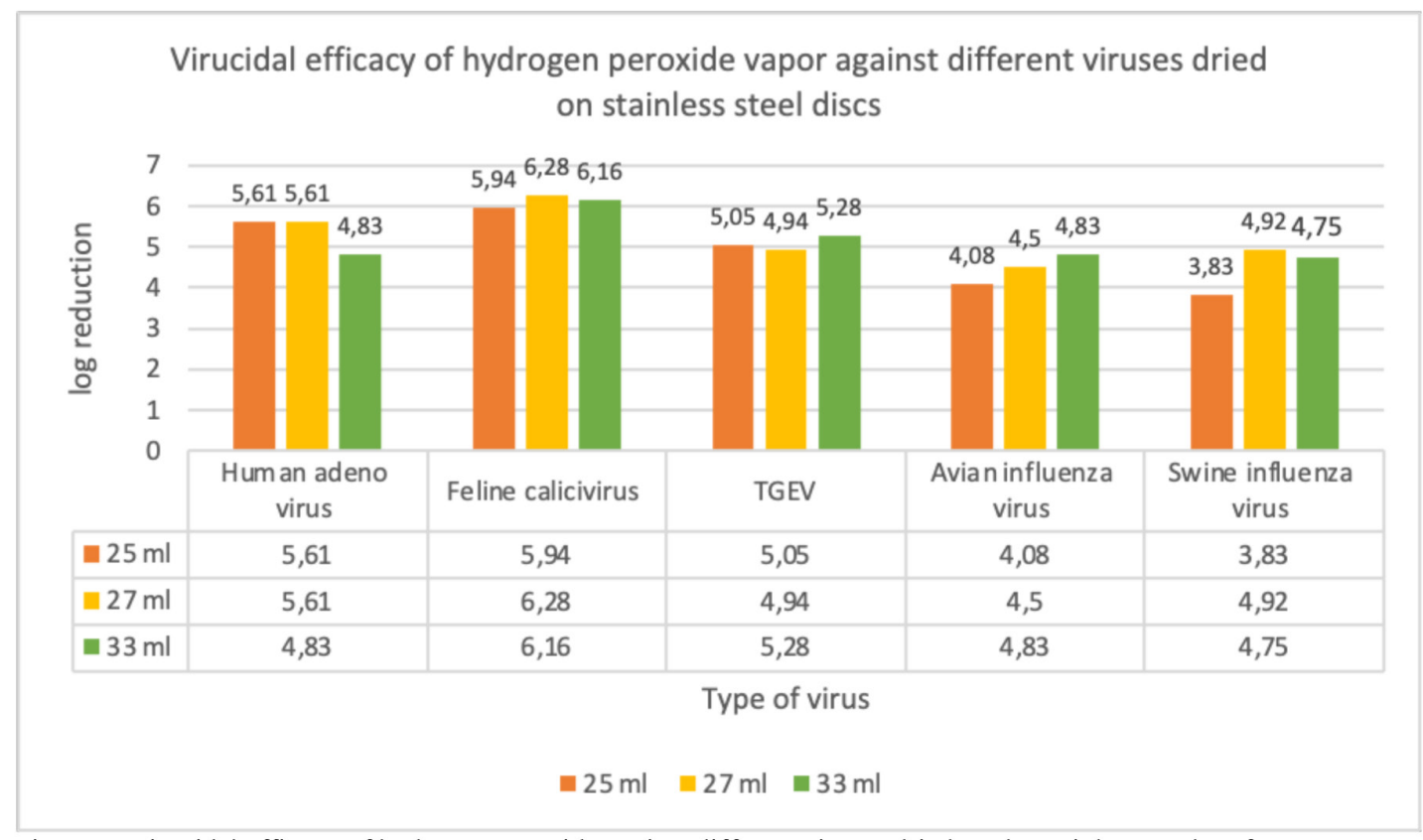

Figure 3. Virucidal efficacy of hydrogen peroxide against different viruses dried on the stainless steel surface 
have been tested to ensure the effectiveness of disinfection. The effects of repeated VHP application on the permeability, morphological features, and fabric unity of the coveralls and $\mathrm{N}-95$ masks were further evaluated. Their experimental studies revealed that in $<10 \mathrm{~min}$, one VHP cycle $\left(7-8 \% \mathrm{H}_{2} \mathrm{O}_{2}\right)$ can effectively disinfect PPE and repeated treatment with VHP did not cause any morphological tear, malformation, or other visible alteration in $\mathrm{N} 95$ masks or coveralls. They believe that VHP treatment can also be successful against less tolerant groups of microorganisms, such as SARS-CoV-2 viruses. Therefore, approximately 2000 PPE bodysuits, which were used in COVID-19 hospital areas, have been successfully processed with a post-disinfection recovery rate of $>80 \% \%^{[59]}$.

Furthermore, the use of $\mathrm{H}_{2} \mathrm{O}_{2}$ vapor can be an efficient way of decontaminating important surrounding areas, such as isolation systems, hospital rooms, technological devices, and pathogenscontaminated areas in general (Figure 4). Andersen et al. ${ }^{[60]}$ examined the effectiveness of $\mathrm{H}_{2} \mathrm{O}_{2}$ in the decontamination of rooms, ambulances, and medical devices in hospitals. According to the volume of the garages and rooms, they used an $\mathrm{H}_{2} \mathrm{O}_{2}$ dry gas device programmed at a pre-set concentration of 12-60 ppm per application cycle. For repeated tests (using B. atrophaeus), 1-3 cycles were used, accompanied by increased contact times of 30,60, and $120 \mathrm{~min}$, sequentially. Decontamination was successful using the three decontaminating cycles in $87 \%$ of 146 tests in special test rooms and 100\% of 48 tests in the rooms of the surgical department.

\section{Conclusion}

In most hospitals, chloride disinfectants are commonly used, but thorough manual sanitation of surfaces may be insufficient to completely control the contaminants or virus transmission. Moreover, chloride gas can cause severe damage to humankind and the environment. Therefore, alternative methods with better performance and fewer side effects should be replaced. These alternative methods include UV radiation, $\mathrm{H}_{2} \mathrm{O}_{2^{\prime}}$ ozone, and $\mathrm{CP}$. The potency of these substitute approaches against SARSCoV-2 has been proven, and utilization of these techniques does not lead to acute problems, which are usually caused by chlorine-based disinfectants. Therefore, the application of these techniques is highly recommended for the disinfection of surfaces, air, and PPE to prevent the nosocomial transmission of SARS-CoV-2.

\section{Acknowledgment}

The author highly thank Dr. Kevin Keener, Dr. Vanessa Rios De Souza, Lillian McClure, and Nooshin Nikmaram for their help and constructive comments.

\section{Ethics}

Peer-review: Externally peer-reviewed.

Financial Disclosure: The author declared that this study received no financial support.

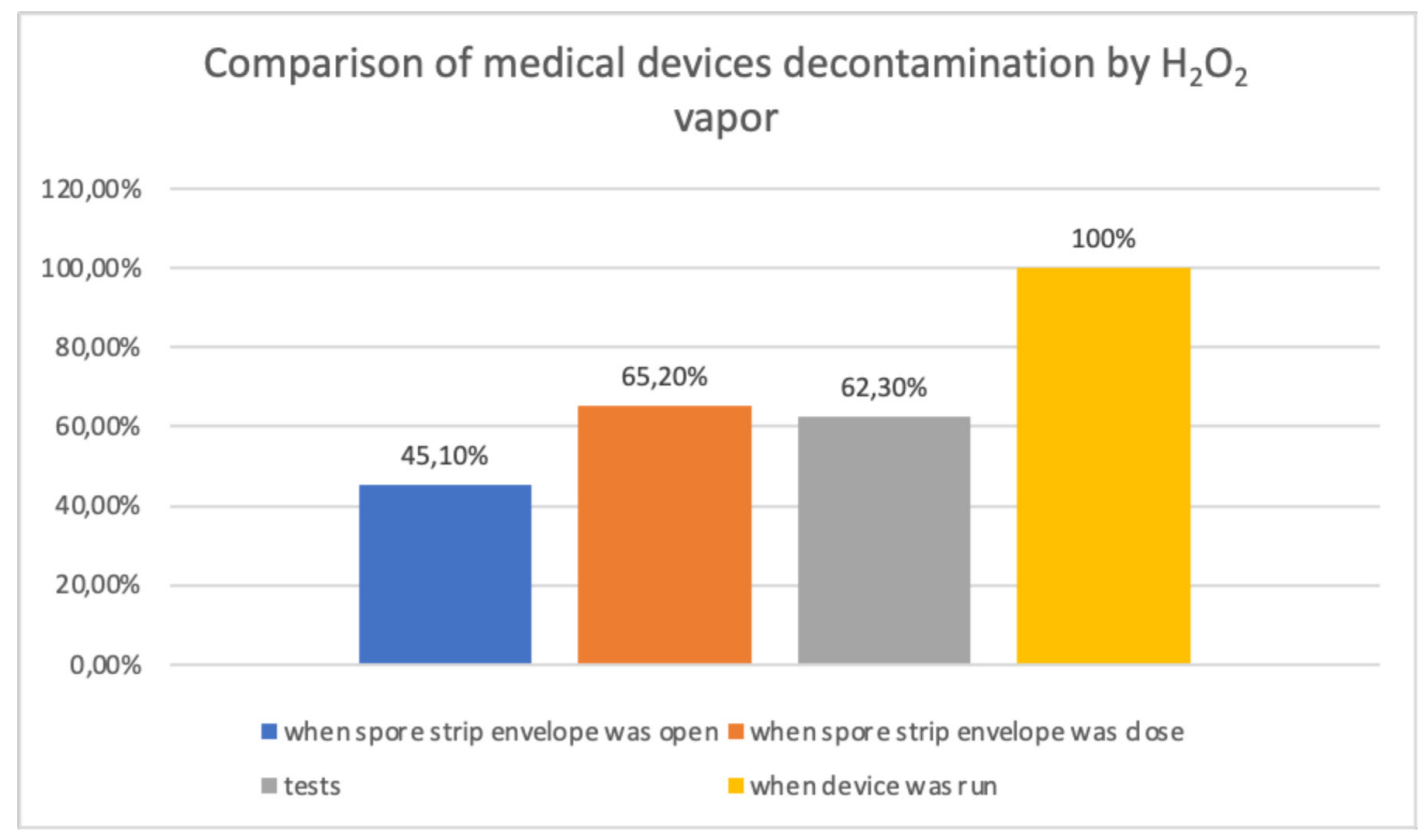

Figure 4. The comparison of medical devices decontamination by hydrogen peroxide vapor 


\section{References}

1. Hoffmann $M$, Kleine-Weber $H$, Schroeder $S$, Krüger $N$, Herrler T, Erichsen S, Schiergens TS, Herrler G, Wu NH, Nitsche A, Müller MA, Drosten C, Pöhlmann S. SARS-CoV-2 Cell Entry Depends on ACE2 and TMPRSS2 and Is Blocked by a Clinically Proven Protease Inhibitor. Cell. 2020;181:271-80.

2. Zandi M, Farahani A, Zakeri A, Akhavan Rezayat $S$, Mohammadi R, Das U, Dimmock JR, Afzali S, Nakhaei MA, Doroudi A, Erfani Y, Soltani S. Clinical Symptoms and Types of Samples Are Critical Factors for the Molecular Diagnosis of Symptomatic COVID-19 Patients: A Systematic Literature Review. Int J Microbiol. 2021;2021:5528786.

3. Wake RM, Morgan M, Choi J, Winn S. Reducing nosocomial transmission of COVID-19: Implementation of a COVID-19 triage system. Clin Med (Lond). 2020;20:141-5.

4. Chan JF, Yuan S, Kok KH, To KK, Chu H, Yang J, Xing F, Liu J, Yip CC, Poon RW, Tsoi HW, Lo SK, Chan KH, Poon VK, Chan WM, Ip JD, Cai JP, Cheng VC, Chen $\mathrm{H}$, Hui CK, Yuen KY. A familial cluster of pneumonia associated with the 2019 novel coronavirus indicating person-to-person transmission: a study of a family cluster. Lancet. 2020;395:514-23.

5. Otter JA, Donskey C, Yezli S, Douthwaite S, Goldenberg SD, Weber DJ. Transmission of SARS and MERS coronaviruses and influenza virus in healthcare settings: The possible role of dry surface contamination. J Hosp Infect. 2016;92:235-50.

6. Niud Y, Xu F. Deciphering the power of isolation in controlling COVID-19 outbreaks. Lancet Glob Health. 2020;8:452-3.

7. Mahmood SU, Crimbly F, Khan S, Choudry E, Mehwish S. Strategies for Rational Use of Personal Protective Equipment (PPE) Among Healthcare Providers During the COVID-19 Crisis. Cureus. 2020;12:e8248.

8. Interim guidance [Internet]. 2020 [cited 2021 Feb 8]. Available from: https://www.who.int/csr/resources/publications/putontakeoff

9. Nogee D, Tomassoni AJ. Covid-19 and the N95 respirator shortage: Closing the gap. Infect Control Hosp Epidemiol. 2020;41:958.

10. Derraik JGB, Anderson WA, Connelly EA, Anderson YC. Rapid Review of SARS-CoV-1 and SARS-CoV-2 Viability, Susceptibility to Treatment, and the Disinfection and Reuse of PPE, Particularly Filtering Facepiece Respirators. Int J Environ Res Public Health. 2020;17:6117.

11. To KK, Hung IF, Ip JD, Chu AW, Chan WM, Tam AR, Fong CH, Yuan S, Tsoi HW, Ng AC, Lee LL, Wan P, Tso EY, To WK, Tsang DN, Chan KH, Huang JD, Kok KH, Cheng VC, Yuen KY. Coronavirus Disease 2019 (COVID-19) Re-infection by a Phylogenetically Distinct Severe Acute Respiratory Syndrome Coronavirus 2 Strain Confirmed by Whole Genome Sequencing. Clin Infect Dis. 2021;73:2946-51.

12. Choi $H$, Chatterjee $P$, Lichtfouse $E$, Martel JA, Hwang $M$, Jinadatha $C$ Sharma VK. Classical and alternative disinfection strategies to control the COVID-19 virus in healthcare facilities: a review. Environ Chem Lett. 2021:1-7.

13. Star EG, Caselitz J, Loening T. The effect of ethylene oxide and chemical disinfectant residues upon the larynx- and tracheal mucosa of rabbits. Zentralbl Bakteriol Mikrobiol Hyg B. 1980;170(5-6):539-47. Available from: https://europepmc.org/article/med/7424289

14. DeLeo PC, Huynh C, Pattanayek M, Schmid KC, Pechacek N. Assessment of ecological hazards and environmental fate of disinfectant quaternary ammonium compounds. Ecotoxicol Environ Saf. 2020;206:111116.

15. Nimonkar SV, Belkhode VM, Godbole SR, Nimonkar PV, Dahane T, Sathe S. Comparative evaluation of the effect of chemical disinfectants and ultraviolet disinfection on dimensional stability of the polyvinyl siloxane impressions. J Int Soc Prev Community Dent. 2019;9:152-8.

16. Lai MYY, Cheng PKC, Lim WWL. Survival of severe acute respiratory syndrome coronavirus. Clin Infect Dis. 2005;41:67-71.
17. Pendyala B, Patras A, Pokharel B, D'Souza D. Genomic Modeling as an Approach to Identify Surrogates for Use in Experimental Validation of SARS-CoV-2 and HuNoV Inactivation by UV-C Treatment. Front Microbiol. 2020;11:572331.

18. Turgeon N, Toulouse MJ, Martel B, Moineau S, Duchaine C. Comparison of five bacteriophages as models for viral aerosol studies. Appl Environ Microbiol. 2014;80:4242-50.

19. Gill J, Hyman P. Phage Choice, Isolation, and Preparation for Phage Therapy. Curr Pharm Biotechnol. 2010;11:2-14.

20. Krupovič $M$, Bamford DH. Virus evolution: How far does the double $\beta$-barrel viral lineage extend? Nat Rev Microbiol. 2008;6:941-8.

21. Verreault D, Moineau S, Duchaine C. Methods for Sampling of Airborne Viruses. Microbiol Mol Biol Rev. 2008;72:413-44.

22. Dev Kumar G, Mishra A, Dunn L, Townsend A, Oguadinma IC, Bright KR, Gerba CP. Biocides and Novel Antimicrobial Agents for the Mitigation of Coronaviruses. Front Microbiol. 2020;11:1351.

23. Darnell MER, Taylor DR. Evaluation of inactivation methods for severe acute respiratory syndrome coronavirus in noncellular blood products. Transfusion. 2006;46:1770-7

24. Raeiszadeh $M$, Adeli B. A Critical Review on Ultraviolet Disinfection Systems against COVID-19 Outbreak: Applicability, Validation, and Safety Considerations. ACS Photonics. 2020;7:2941-51.

25. Tseng CC, Li CS. Inactivation of Viruses on Surfaces by Ultraviolet Germicidal Irradiation. J Occup Environ Hyg. 2007;4:400-5.

26. Jinadatha C, Simmons $S$, Dale C, Ganachari-Mallappa N, Villamaria FC, Goulding N, Tanner B, Stachowiak J, Stibich M. Disinfecting personal protective equipment with pulsed xenon ultraviolet as a risk mitigation strategy for health care workers. Am J Infect Control. 2015;43:412-4.

27. Rubio-Romero JC, Pardo-Ferreira MDC, Torrecilla-García JA, Calero-Castro S. Disposable masks: Disinfection and sterilization for reuse, and noncertified manufacturing, in the face of shortages during the COVID-19 pandemic. Saf Sci. 2020;129:104830.

28. Lindsley WG, Martin SB Jr, Thewlis RE, Sarkisian K, Nwoko JO, Mead KR, Noti JD. Effects of Ultraviolet Germicidal Irradiation (UVGI) on N95 Respirator Filtration Performance and Structural Integrity. J Occup Environ Hyg. 2015;12:509-17.

29. Morrison C, Atkinson A, Zamyadi A, Kibuye F, McKie M, Hogard S, Mollica P, Jasim S, Wert EC. Critical Review and Research Needs of Ozone Applications Related to Virus Inactivation: Potential Implications for SARS-CoV-2. Ozone Sci Eng. 2021;43:2-20.

30. Cristiano L. Could ozone be an effective disinfection measure against the novel coronavirus (SARS-CoV-2)? J Prev Med Hyg. 2020;61:301-3.

31. Tseng CC, Li CS. Ozone for Inactivation of Aerosolized Bacteriophages. Aerosol Sci Technol. 2006;40:683-9.

32. Rojas-Valencia MN. Research on Ozone Application as Disinfectant and Action Mechanisms on Wastewater Microorganisms. 2021. https://www. researchgate.net/publication/265050308

33. Alimohammadi M, Naderi M. Effectiveness of Ozone Gas on Airborne Virus Inactivation in Enclosed Spaces: A Review Study. Ozone Sci Eng. 2021;43:21-31.

34. Hudson JB, Sharma M, Vimalanathan S. Development of a Practical Method for Using Ozone Gas as a Virus Decontaminating Agent. Ozone Sci Eng. 2009;31:216-23.

35. Tizaoui C. Ozone: A Potential Oxidant for COVID-19 Virus (SARS-CoV-2) Ozone Sci Eng. 2020;42:378-85.

36. Zucker I, Lester Y, Alter J, Werbner M, Yecheskel Y, Gal-Tanamy M, Dessau M. Pseudoviruses for the assessment of coronavirus disinfection by ozone. Environ Chem Lett. 2021:1-7. 
37. Perry JJ, Yousef AE. Decontamination of Raw Foods Using Ozone-Based Sanitization Techniques. Annu Rev Food Sci Technol. 2011;2:281-98.

38. Gupta G, Mansi B. Ozone therapy in periodontics. J Med Life. 2012;5:59-67.

39. Kashiwazaki J, Nakamura K, Hara Y, Harada R, Wada I, Kanemitsu K. Evaluation of the Cytotoxicity of Various Hand Disinfectants and Ozonated Water to Human Keratinocytes in a Cultured Epidermal Model. Adv Skin Wound Care. 2020;33:313-8.

40. Blanchard EL, Lawrence JD, Noble JA, Xu M, Joo T, Ng NL, Schmidt BE, Santangelo PJ, Finn MG. Enveloped Virus Inactivation on Personal Protective Equipment by Exposure to Ozone. medRxiv. 2020:2020

41. Dennis $R$, Pourdeyhimi B, Cashion A, Emanuel $S$, Hubbard D. Durability of Disposable N95 Mask Material When Exposed to Improvised Ozone Gas Disinfection. J Sci Med. 2020:2.

42. Filipić A, Primc G, Zaplotnik R, Mehle N, Gutierrez-Aguirre I, Ravnikar M, Mozetič M, Žel J, Dobnik D. Cold Atmospheric Plasma as a Novel Method for Inactivation of Potato Virus $Y$ in Water Samples. Food Environ Virol. 2019;11:220-8.

43. Guo J, Huang $K$, Wang J. Bactericidal effect of various non-thermal plasma agents and the influence of experimental conditions in microbial inactivation: A review. Food Control 2015;50:482-90

44. Yusupov M, Neyts EC, Khalilov U, Snoeckx R, Van Duin ACT, Bogaerts A. Atomic-scale simulations of reactive oxygen plasma species interacting with bacterial cell walls. New J Phys. 2012;14:93043-61.

45. Chen Z, Wirz RE. Preprints (www.preprints.org) | NOT PEER-REVIEWED | Posted. 2020 [cited 2021 Feb 12];Available from: www.preprints.org

46. Mozetič $M$, Vesel A, Primc G, Zaplotnik R. Introduction to Plasma and Plasma Diagnostics. In: Non-Thermal Plasma Technology for Polymeric Materials. Elsevier, 2019:23-65.

47. Alshraiedeh NH, Alkawareek MY, Gorman SP, Graham WG, Gilmore BF. Atmospheric pressure, nonthermal plasma inactivation of MS2 bacteriophage: effect of oxygen concentration on virucidal activity. J Appl Microbiol. 2013;115:1420-6.

48. Wu Y, Liang Y, Wei K, Li W, Yao M, Zhang J, Grinshpun SA. MS2 virus inactivation by atmospheric-pressure cold plasma using different gas carriers and power levels. Appl Environ Microbiol. 2015;81:996-1002.

49. Sakudo A, Toyokawa Y, Imanishi Y, Murakami T. Crucial roles of reactive chemical species in modification of respiratory syncytial virus by nitrogen gas plasma. Mater Sci Eng C Mater Biol Appl. 2017;74:131-6.

50. Puligundla $\mathrm{P}$, Mok C, Pradeep $\mathrm{P}$, Chulkyoon M. Non-thermal plasmas (NTPs) for inactivation of viruses in abiotic environment. Res J Biotech. 2016;11:91-6.
51. Chen Z, Garcia G Jr, Arumugaswami V, Wirz RE. Cold atmospheric plasma for SARS-CoV-2 inactivation. Phys Fluids. 2020;32:111702.

52. Pottage T, Richardson C, Parks S, Walker JT, Bennett AM. Evaluation of hydrogen peroxide gaseous disinfection systems to decontaminate viruses. J Hosp Infect. 2010;74:55-61.

53. Goyal SM, Chander Y, Yezli S, Otter JA. Evaluating the virucidal efficacy of hydrogen peroxide vapour. J Hosp Infect. 2014;86:255-9.

54. McDonnell G. The Use of Hydrogen Peroxide for Disinfection and Sterilization Applications. Chichester, UK: John Wiley \& Sons, Ltd, 2014:1-34.

55. Fisher JR, Caputo RA. Comparing and contrasting: Barrier isolator decontamination systems. undefined, 2004.

56. Heckert RA, Best $M$, Jordan LT, Dulac GC, Eddington DL, Sterritt WG Efficacy of vaporized hydrogen peroxide against exotic animal viruses. Appl Environ Microbiol. 1997;63:3916-8.

57. Barbut $F$, Yezli $S$, Otter JA. Activity in vitro of hydrogen peroxide vapour against Clostridium difficile spores. J Hosp Infect. 2012;80:85-7.

58. Otter JA, Yezli S, Perl TM, Barbut F, French GL. The role of "no-touch" automated room disinfection systems in infection prevention and control. J Hosp Infect. 2013;83:1-13.

59. Saini V, Sikri K, Batra SD, Kalra P, Gautam K. Development of a highly effective low-cost vaporized hydrogen peroxide-based method for disinfection of personal protective equipment for their selective reuse during pandemics. Gut Pathog 2020;12:29.

60. Andersen BM, Rasch $M$, Hochlin $K_{1}$ Jensen FH, Wismar P, Fredriksen JE. Decontamination of rooms, medical equipment and ambulances using an aerosol of hydrogen peroxide disinfectant. J Hosp Infect. 2006;62:149-55.

61. Kampf G, Todt D, Pfaender S, Steinmann E. Persistence of coronaviruses on inanimate surfaces and their inactivation with biocidal agents. J Hosp Infect. 2020;104:246-51.

62. Derraik JGB, Anderson WA, Connelly EA, Anderson YC. Rapid Review of SARS-CoV-1 and SARS-CoV-2 Viability, Susceptibility to Treatment, and the Disinfection and Reuse of PPE, Particularly Filtering Facepiece Respirators. Int J Environ Res Public Health. 2020;17:6117.

63. Heßling $M$, Hönes $K_{1}$ Vatter $P$, Lingenfelder $C$. Ultraviolet irradiation doses for coronavirus inactivation - review and analysis of coronavirus photoinactivation studies. GMS Hyg Infect Control. 2020;15:1-8.

64. Tseng CC, Li CS. Ozone for Inactivation of Aerosolized Bacteriophages. Aerosol Sci Technol. 2021;40:683-9. 